\title{
The behavioral ecology of variation in social insects
}

\section{J. M.Jandt ${ }^{\mathrm{a}^{*}}{ }_{1}$ and D. M. Gordon ${ }^{\mathrm{b}}$}

a Iowa State University, Department of Ecology, Evolution, and Organismal Biology, 251 Bessey Hall, Ames, IA 50011, U.S. jjandt2@gmail.com

b Stanford University, Department of Biology, Gilbert Biological Sciences Building rm 410, 371 Serra Mall, Stanford, CA 94305, U.S. dmgordon@stanford.edu

* Corresponding Author

1 Present Address: Otago University, Department of Zoology, 340 Great King Street, Dunedin 9016, New Zealand, jenny.jandt@otago.ac.nz

\begin{abstract}
Understanding the ecological relevance of variation within and between colonies has been an important and recurring theme in social insect research.Recent research addresses the genomic and physiological factors and fitness effects associated with behavioral variation, within and among colonies, in regulation of activity, cognitive abilities, and aggression. Behavioral variation among colonies has consequences for survival and reproductive success that are the basis for evolutionary change.
\end{abstract}




\section{Introduction}

Investigating the sources of variation has been an important and recurring theme in social insect research[1].Here we consider variation at two levels: among individuals within colonies, and among colonies within populations. Because of space limitations we do not provide a comprehensive review; each of our citations is only one or two examples out of many studies.

Variation among individuals within colonies is ubiquitous. In addition, evidence is growing that colonies vary, which means that the range of individual phenotypes in one colony differs from the range in another. The behavior of colony A differs from the behavior of colony B because the combined outcome of the range of behavior among individuals of colony A differs from that combined outcome for colony B.

Many kinds of phenotypic differences lead to both individual and colony variation (reviewed in [2-4]); including: life-history traits (i.e., growth, reproduction, and queen mating frequency [5-10]), morphological traits related to social behavior and physiology[11-18], andbehavioral traits (i.e., regulation of activity, cognitive abilities, or aggression and nestmate recognition[19-21]).The development and maintenance of individual and colony variation is influenced by resource availability, abiotic conditions along a geographic cline, social interactions within and between colonies, and population-level genetic factors such as dependent lineages(reviewed in [22]).In most cases, we don't know the source of variation among individuals or colonies. Mutation, small differences in microclimate and resource availability, the developmental noise that leads organisms with the same genes to differ, all probably contribute to the variation that we observe.

\section{Behavioral Variation}

Regulation of activity

Individuals within a colony may exhibit consistent behavioral variation(see Table 2 in[3])in their propensity to perform particular tasks [19]. Whether individuals work inside or outside the nest may be associated with a tendency to be in a certain location inside the nest, which affects the probability of interaction with 
nestmates [23,24]. In the ant Myrmica rubra, individuals that forage outside the nest are more active, exploratory, aggressive, and attracted to light than individuals that work inside nest[25]. Individuals often move from one task to another as they age, e.g., from in-nest brood care to nest cleaning to out-of-nest foraging. The mechanisms for this have been best studied in honey bees (reviewed in[26]). In the antCamponotus fellah, the age-mediated transition from in-nest to foraging tasks also corresponds to changes in social interaction networks[23].Individuals within a colony may also vary in foraging strategies. In Ectatomma ruidum, some foragers are more likely to collect food bystealing from neighboring nests while others are more likely to collect food by searching the leaf-litter $[27,28]$. Colony variation in foraging behavior may then arise from variation in the foraging strategies of individuals.

Studies on behavioral variation among colonies have focused on the regulation of activity [29-33];e.g., foraging behavior[34], thermoregulation, and nest cleaning[35].Harvester ant colonies differ consistently, from year to year, in the extent to which they curtail foraging activity in dry conditions. Because individual ants live only a year (whereas the queen lives for 20-30 years, and doesn't begin producing new reproductives until she is 5 [36]), consistent differences are apparently inherited in successive cohorts of workers[37]. Since the regulation of foraging depends on interactions between outgoing and returning foragers [38,39], it is likely that differences among colonies arise from the variation in individual sensitivity to interactions.

Colonies of bumble bees[40] and honey bees[41]vary in the extent of nectar and pollen foraging. In honey bees, genomic and physiological differences are associated with consistent within-colony variationin individual foraging behavior[26,42].Social insect coloniesalso vary in their ability to thermoregulate and clean the nest [35], probably due to physiological variation among individuals within the colonyin ability to perceive temperature fluctuations $[43,44]$ or dead nestmatesandparasites[35,45,46].

\section{Cognitive Abilities}


Individuals and colonies vary in learning, memory, sensory bias, and decision-making [3].In bumblees, rapid learning is correlated with the ability to remember visual cues[47], and rate of decision-making is associated with nectar foraging[48]. Colonies that learn more slowly harvest less nectar compared to the fastest learning colonies [49].Colonies also vary in sensory bias, such as color preferences, which may be associated with variation in foragingsuccess and exploratory behavior [50]. For example, colonies of bumble bees that prefer violet collect more nectar than those that prefer blue [48]).

\section{Aggression and Nestmate Recognition}

Individuals and colonies may both vary in aggression towardindividuals of other colonies [3]. Differences among colonies in cuticular hydrocarbon (CHC) profile are the basis for nestmate recognition in most social insects. The results of nestmate recognition experiments in ants suggest that individuals modify over time their response to the odorsof different ants that they meet, so that at any time individuals differ in their responses. Collectively, colonies respond because there are some ants that can identify the odor of any intruder as that of a nonnestmate[21]. Empirical studies suggest that environmental factors might predict CHC profile better than colony of origin [51-53]. For example, leaf-cutter ant colonies (Atta sextens) that forage on the same plants have similar CHC profiles and are less aggressive toward one another than toward conspecifics with a different $\operatorname{diet}[54]$.

In some Polistes spp.(Vespidae), individuals assess variation among workers by their facial patterns. In P. dominula, specific facial patterns, such as the distribution of the black pigment on the clypeus, are associated with dominance rank and nesting success [55]. In P. fuscatus, workers can distinguish individual faces of both nestmates and non-nestmates [56].In the hover wasp, Liostenogaster flavolineata (Stenogastrinae), individuals prioritize visual facial cues over $\mathrm{CHC}$ profiles to distinguish nestmates [57].

An individual's age or size may be associated with aggression or exploratory behavior. For example, aggression in the wasp, Vespula vulgaris, tends to increase 
with age [58]. In the ant Leptothorax acervorum, older workers with well-developed ovaries tend to be more aggressive and active than younger ones [59]. In some ant species, larger or major workers tend to be more aggressive than smaller workers (e.g., Acromyrmex echinatior, [60]; Oecophylla smaragdina,[61]).

Aggressive behavior appears to be heritable (reviewed for honey bees in [26]), but changes in gene expression are also associated with variation in aggressive behavior. In weaver ants, high expression of octopamine is linked to aggressive behavior[61], whereas in honey bees, octopamine, as well as glutamate and GABA signaling, is linked to exploratory behavior [62,63]. Aggression in honey bees, as well as in Polistes metricus paper wasps, is linked to a decrease in oxidative phosphorylation [64-66].

\section{Ecological sources and outcomes of variation}

Environmental conditions lead to variation among colonies in life history traits within a species across a geographic cline. For example, a temperature gradient is associated with variation in colony growth and activity in subterranean termites[67,68]. Gradients in environmental conditions are associated with intraspecific variation among colonies in life-history and breeding structure [69-71], in resource use[30], and in interactions with other colonies [72] or other species such as pathogens [73-75] and parasitoids [76].

Variation among colonies in behavior can have important ecological effects. For example, differences among harvester ant colonies in the regulation of foraging by feedback from ant-ant interactions[29,77], are associated with differences in reproductive success, in numbers of offspring colonies[37,78]. This suggests that selection is acting on variation among colonies in how individuals respond to interactions. Colony variation in interaction networks can lead to differences in parasite load and susceptibility to infection $[79,80]$.

Variation among colonies may facilitate rapid evolution of invasive species[81,82]. Aggressive and active colonies may have a competitive advantage inthe invasive range [83,84], until population densities become very high[82]. When 
the invasive wasp Vespa velutina is sympatric with the native wasp Vespa crabro, its foundresses tend to be more active, bolder, and more exploratory than the native species [85]. On the other hand, there is more variation in these traits among the native $V$. crabro foundresses, perhaps because of a genetic bottleneck effect on $V$. velutina when they were introduced [85]. In the fire ant (Solenopsis invicta), colonies vary in queen number, due to epigenetic processes involving large numbers of genes [86]. A polygynous form spread within the invasive range [87] that may be associated with a decrease in aggression and higher population densities [88].

\section{Conclusions}

Investigating the sources of variation is a central question in evolutionary biology. Variation is a fundamental element of the phenotypes that matter ecologically, and it is the starting point for evolutionary change. Variation among individuals, and among colonies, arises from differences in their behavioral, physiological and epigenetic response to their environments. Environments change, sometimes because organisms modify them, and this amplifies variation. It seems likely that when we compare individuals and colonies in any aspect of their biology, we will find that they vary.

\section{Acknowledgements}

JM Jandt acknowledges funding provided by NSF: IOS-1146410.

\section{References}

1. Jeanne RL: Interindividual behavioral variability in social insects. Westview Press; 1988.

2. LeBoeuf AC, Grozinger CM: Me and we: the interplay between individual and group behavioral variation in social collectives. Current Opinion in Insect Science 2014, 5:16-24.

3. Jandt JM, Bengston S, Pinter-Wollman N, Pruitt JN, Raine NE, Dornhaus A, Sih A: Behavioural syndromes and social insects: personality at multiple levels. Biological Reviews 2014, 89:48-67.

4. Jeanson $\mathrm{R}$, Weidenmuller A: Interindividual variability in social insects proximate causes and ultimate consequences. Biological Reviews 2014, 89:671-687. 
5. Marti HE, Carlson AL, Brown BV, Mueller UG: Foundress queen mortality and early colony growth of the leafcutter ant, Atta texana (Formicidae, Hymenoptera). Insectes Sociaux 2015, 62:357-363.

6. Miyazaki S, Yoshimura M, Saiki R, Hayashi Y, Kitade O, Tsuji K, Maekawa K: Intracolonial genetic variation affects reproductive skew and colony productivity during colony foundation in a parthenogenetic termite. BMC Evolutionary Biology 2014, 14:177.

7. Wills BD, Moreau CS, Wray BD, Hoffmann BD, Suarez AV: Body size variation and caste ratios in geographically distinct populations of the invasive big-headed ant, Pheidole megacephala (Hymenoptera:

Formicidae) Biological Journal of the Linnean Society 2014, 113:423-428.

8. Kramer BH, Schrempf A, Scheuerlein A, Heinze J: Ant colonies do not trade-off reproduction against maintenance. PLOS ONE 2015, 10:e0137969.

9. Loope KJ, Chien C, Juhl M: Colony size is linked to paternity frequency and paternity skew in yellowjacket wasps and hornets. BMC Evolutionary Biology 2014, 14:277.

10. Heinze J, Gratiashvili N: High skew in the Caucasus: functional monogyny in the ant Leptothorax samni. Insectes Sociaux 2015, 62:385-392.

11. Alvarado S, Rajakumar R, Abouheif E, Szyf M: Epigenetic variation in the $\boldsymbol{E g} \boldsymbol{f r}$ gene generates quantitative variation in a complex trait in ants. Nature Communications 2015, 6.

*The production of large workers in a stingless bee depends on the spatial arrangement of brood inside the nest. Larvae reared in the center of the nest grow in larger cells and are provisioned with more food than those raised elsewhere. Larger bees are more likely to guard the nest than smaller ones.

12. Rajakumar R, San Mauro D, Dijkstra MB, Huang MH, Wheeler DE, Hiou-Tim F, Khila A, Cournoyea M, Abouheif E: Ancestral developmental potential facilitates parallel evolution in ants. Science 2012, 335:79-82.

13. Grüter C, Menezes C, Imperatriz-Fonseca VL, Ratnieks FLW: A morphologically specialized soldier caste improves colony defense in a neotropical eusocial bee. Proceedings of the National Academy of Sciences of the United States of America 2012, 109:1182-1186.

14. Segers FHID, Menezes C, Vollet-Neto A, Lambert D, Grüter C: Soldier production in a stingless bee depends on rearing location and nurse behaviour. Behavioral Ecology and Sociobiology 2015, 69:613-623.

*The production of large workers in a stingless bee depends on the spatial arrangement of brood inside the nest. Larvae reared in the center of the nest grow in larger cells and are provisioned with more food than those raised elsewhere. Larger bees are more likely to to guard the nest than smaller ones.

15. del Castillo RC, Sanabria-Urbán S, Serrano-Meneses MA: Trade-offs in the evolution of bumblebee colony and body size: a comparative analysis. Ecology and Evolution 2015, 5:3914-3926.

16. Westling JN, Harrington K, Bengston S, Dornhaus A: Morphological differences between extranidal and intranidal workers in the ant Temnothorax 
rugatulus, but no effect of body size on foraging distance Insectes Sociaux 2014, 61:367-369.

17. Baudier KM, Mudd AE, Erickson SC, O'Donnell S: Microhabitat and body size effects on heat tolerance: implications for responses to climate change (army ants: Formicidae, Ecitoninae). Journal of Animal Ecology 2015, 84:1322-1330.

18. Couvillon MJ, Dornhaus A: Small worker bumble bees (Bombus impatiens) are hardier against starvation than their larger sisters. Insectes Sociaux 2010, 57:193-197.

19. Gordon DM: From division of labor to collective behavior. Behavioral Ecology and Sociobiology 2015.

*Variation among workers within colonies arises from the interplay of worker interactions with each other and their environments. This leads to ecologically important variation among colonies.

20. Raine NE, Chittka L: The adaptive significance of sensory bias in a foraging context: floral colour preferences in the bumblebee Bombus terrestris. Plos One 2007, 2.

21. Esponda F, Gordon DM: Distributed nestmate recognition in ants. Proceedings of the Royal Society B-Biological Sciences 2015, 282:20142838.

22. Bengston SE, Jandt JM: The development of collective personality: the ontogenetic drivers of behavioral variation across groups. Frontiers in Ecology and Evolution 2014, 2:81.

23. Mersch DP, Crespi A, Keller L: Tracking individuals shows spatial fidelity is a key regulator of ant social organization Science 2013, 340:1090-1093.

24. Pinter-Wollman N: Persistent variation in spatial behavior affects the structure and function of interaction networks. Current Zoology 2015, 61:98-106.

25. Pamminger T, Foitzik S, Kaufmann KC, Schutzler N, Menzel F: Worker personality and its association with spatially structured division of labor. Plos One 2014, 9:e79616.

26. Dolezal A, Toth A: Honey bee sociogenomics: a genome-scale perspective on bee social behavior and health. Apidologie 2014, 45:375-395.

27. Jandt JM, Hunt EM, McGlynn TP: Intraspecific food-robbing and neighborhood competition: consequences for anti-robber vigilance and colony productivity. Biotropica 2015, 47:491-496.

28. McGlynn TP, Graham R, Wilson J, Emerson J, Jandt JM, Jahren AH: Distinct types of foragers in the ant Ectatomma ruidum: typical foragers and furtive thieves. Animal Behaviour 2015, 109:243-247.

29. Gordon DM, Guetz A, Greene MJ, Holmes S: Colony variation in the collective regulation of foraging by harvester ants. Behavioral Ecology 2011, 22:429435.

30. Kleeberg I, Jongepier E, Job S, Foitzik S: Geographic variation in social parasite pressure predicts intraspecific but not interspecific aggressive responses in hosts of a slavemaking ant. Ethology 2015, 121:694-702. 
31. Wray MK, Mattila HR, Seeley TD: Collective personalities in honeybee colonies are linked to colony fitness. Animal Behaviour 2011, 81:559-568.

32. Bockoven AA, Wilder SM, Eubanks MD: Intraspecific variation among social insect colonies: Persistent regional and colony-level differences in fire ant foraging behavior. PLOS ONE 2015, 10:e0133868.

* Fire ant colonies vary in foraging activity, exploration, and discovery of and recruitment to resources. Variation in activity was correlated with colony growth, and there was evidence to suggest that activity and exploration are partially heritable.

33. Pinter-Wollman N, Gordon DM, Holmes S: Nest site and weather affect the personality of harvester ant colonies. Behavioral Ecology 2012, 23:10221029.

34. Johnson BR, Frost E: Individual-level patterns of division of labor in honeybees highlight flexibility in colony-level developmental mechanisms. Behavioral Ecology and Sociobiology 2012, 66:923-930.

35. Jandt JM, Dornhaus A: Bumblebee response thresholds and body size: does worker diversity increase colony performance?Animal Behaviour 2014, 87:97-106.

* Continuous variation in worker size and in fanning in response to temperature increase was measured in bumble bee colonies. Colonies varied in their overall performance of removing dead nestmates and cooling the nest. Colony corpse removal was correlated with the average body size of workers in the nest, whereas colony cooling was correlated with the amount of behavioral variation in the nest.

36. Gordon DM: The development of organization in an ant colony. American Scientist 1995, 83:50-57.

37. Gordon DM: The rewards of restraint in the collective regulation of foraging by harvester ant colonies. Nature 2013, 498:91-93.

38. Pless E, Queirolo J, Pinter-Wollman N, Crow S, Allen K, Mathur MB, Gordon DM: Interactions increase forager availability and activity in harvester ants. 2015, 10:e0141971.

39. Pinter-Wollman N, Bala A, Merrell A, Queirolo J, Stumpe MC, Holmes S, Gordon DM: Harvester ants use interactions to regulate forager activation and availability. Animal Behaviour 2013, 86:197-207

40. Saifuddin M, Jha S: Colony-level variation in pollen collection and foraging preferences among wild-caught bumble bees (Hymenoptera: Apidae). Environmental Entomology 2014, 43:393-401.

41. Oliveira-Abreu C, Hilario SD, Luz CFP, Ales-dos-Santos I: Pollen and nectar foraging by Melipona quadrifasciata anthidioides Lepeletier (Hymenoptera: Apidae: Meliponini) in natural habitat. Sociobiology 2014, 61:441-448.

42. Page RE, Rueppell O, Amdam GV: Genetics of reproduction and regulation of honeybee (Apis mellifera L.) social behavior. Annual Review of Genetics 2012, 46:97-119. 
43. Junca P, Sandoz J-C: Heat perception and aversive learning in honey bees: Putative involvement of the thermal/chemical sensor AmHsTRPA. Frontiers in Physiology 2015, 6:316.

44. Ramirez-Esquivel F, Zeil J, Narendra A: The antennal sensory array of the nocturnal bull ant Myrmecia pyriformis Arthropod Structure \& Development 2014, 43:543-558.

45. Diez L, Moquet L, Detrain C: Post-mortem changes in chemical profile and their influence on corpse removal in ants. 2013, 39:1424-1432.

46. Rocha FH, Lachaud J-P, Valle-Mora J: Fine individual specialization and elitism among workers of the ant Ectatomma tuberculatum for a highly specific task: intruder removal Ethology 2014, 120:1-14.

47. Raine NE, Chittka L: No trade-off between learning speed and associative flexibility in bumblebees: A reversal learning test with multiple colonies. PLOS ONE 2012, 7:e45096.

48. Raine NE, Chittka L: The adaptive significance of sensory bias in a foraging context: floral colour preferences in the bumblebee Bombus terrestris. Plos One 2007, 2.

49. Raine NE, Chittka L: The correlation of learning speed and natural foraging success in bumble-bees. Proceedings of the Royal Society B-Biological Sciences 2008, 275:803-808.

50. Muller H, Grossmann H, Chittka L: 'Personality' in bumblebees: individual consistency in responses to novel colours?Animal Behaviour 2010, 80:1065-1074.

51. Sturgis SJ, Gordon DM: Aggression is task dependent in the red harvester ant (Pogonomyrmex barbatus). Behavioral Ecology 2013, 24:532-539.

52. Liang D, Silverman J: "You are what you eat": diet modifies cuticular hydrocarbons and nestmate recognition in the Argentine ant, Linepithema humile. Naturwissenschaften 2000, 87:412-416.

53. Khidr SK, Linforth RS, Hardy IC: Genetic and environmental influences on the cuticular hydrocarbon profiles of Goniozus wasps. Entomologia Experimentalis et Applicata 2013, 147:175-185.

54. Valadares L, Nascimento D, Nascimento FS: Foliar substrate affects cuticular hydrocarbon profiles and intraspecific aggression in the leafcutter ant Atta sexdens. Insects 2015, 6:141-151.

55. Tibbetts EA, Forrest T, Vernier C, Jinn J, Madagame A: Socially selected ornaments and fitness: Signals of fighting ability in paper wasps are positively associated with survival, reproductive success, and rank.Evolution 2015, 69:2917-2926.

56. Injaian A, Tibbetts EA: Cognition across castes: Individual recognition in worker Polistes fuscatus wasps. Animal Behaviour 2014, 87:91-96.

57. Baracchi D, Petrocelli I, Chittka L, Ricciardi G, Turillazzi S: Speed and accuracy in nest-mate recognition: a hover wasp prioritizes face recognition over colony odour cues to minimize intrusion by outsider. Proceedings of the Royal Society B 2015, 282:20142750. 
58. Santoro D, Hartley S, Suckling DM, Lester PJ: The stinging response of the common wasp (Vespula vulgaris): plasticity and variation in individual aggressiveness. Insectes Sociaux 2015, 62:455-463.

59. Kühbandner S, Modlmeier AP, Foitzik S: Age and ovarian development are related to worker personality and task allocation in the ant Leptothorax acervorum. Current Zoology 2014, 60:392-400.

* Worker behavior, including brood care, aggression, and exploration, was consistent within and across settings. Some workers had a more aggressive and exploratory personality type than others. Ovarian development and age were also associated with worker behavior.

60. Larsen J, Fouks B, Bos N, d'Ettorre P, Nehring V: Variation in nestmate recognition ability among polymorphic leaf-cutting ant workers. Journal of Insect Physiology 2014, 70:59-66.

61. Kamhi JF, Nunn K, Robson SKA, Traniello JFA: Polymorphism and division of labour in a socially complex ant: neuromodulation of aggression in the Australian weaver ant, Oecophylla smaragdina. Proceedings of the Royal Society B-Biological Sciences 2015, 282:20150704.

62. Liang ZS, Nguyen T, Mattila HR, Rodriguez-Zas SL, Seeley TD, Robinson GE: Molecular determinants of scouting behavior in honey bees. Science 2012, 335:1225-1228.

63. Liang ZZS, Mattila HR, Rodriguez-Zas SL, Southey BR, Seeley TD, Robinson GE:

Comparative brain transcriptomic analyses of scouting across distinct behavioural and ecological contexts in honeybees. Proceedings of the Royal Society B-Biological Sciences 2014, 281:20141868.

** Previous work (Liang et al. 2012) showed that honey bees that scouted for food also tended to scout for new nest sites, and that scouting behavior was associated with brain gene expression. Here, Liang et al. further investigate gene expression associated with scouting. Both food and nest scouts exhibit similar patterns of glutamate- and GABA-related genes, but differ in their expression of other genes, such as odour-binding protein 4 .

64. Chandrasekaran S, Rittschof CC, Djukovic D, Gu H, Raftery D, Price ND, Robinson GE: Aggression is associated with aerobic glycolysis in the honey bee brain. Genes Brain and Behavior 2015, 14:158-166.

65. Li-Byarlay H, Rittschof CC, Massey JH, Pittendrigh BR, Robinson GE: Socially responsive effects of brain oxidative metabolism on aggression. Proceedings of the National Academy of Sciences of the United States of America 2014, 111:12533-12537.

66. Toth AL, Tooker JF, Radhakrishnan S, Minard R, Henshaw MT, Grozinger CM:

Shared genes related to aggression, rather than chemical communication, are associated with reproductive dominance in paper wasps (Polistes metricus). BMC Genomics 2014, 15:75.

67. Vargo EL, Leniaud L, Swoboda LE, Diamond SE, Weiser MD, Miller DM, Bagneres AG: Clinal variation in colony breeding structure and level of inbreeding 
in the subterranean termites Reticulitermes flavipes and $\boldsymbol{R}$.

grassei Molecular Ecology 2013, 22:1447-1462.

68. Fucini S, Uboni A, Lorenzi MC: Geographic variation in air temperature leads to intraspecific variability in the behavior and productivity of a eusocial insect. Journal of Insect Behavior 2014, 27:403-410.

69. Purcell J, Pellissier L, Chapuisat M: Social structure varies with elevation in an Alpine ant. Molecular Ecology 2015, 24:498-507.

70. Helms KR, Cahan SH: Large-scale regional variation in cooperation and conflict among queens of the desert ant Messor pergandei. 2012, 84:499507.

71. Sheehan MJ, Botero CA, Hendry TA, Sedio BE, Jandt JM, Weiner S, Toth AL, Tibbetts EA: Different axes of environmental variation explain the presence vs. extent of cooperative nest founding associations in Polistes paper wasps. Ecology Letters 2015, 18:1057-1067.

72. Bengston SE, Dornhaus A: Latitudinal variation in behaviors linked to risk tolerance is driven by nest-site competition and spatial distribution in the ant Temnothorax rugatulus. Behavioral Ecology and Sociobiology 2015, 69:1265-1274.

73. Valles SM, Oi DH, Porter SD: Seasonal variation and the co-occurrence of four pathogens and a group of parasites among monogyne and polygyne fire ant colonies. Biological Control 2010, 54:342-348.

74. McMahon DP, Furst MA, Caspar J, Theodorou P, Brown MJF, Paxton RJ: A sting in the spit: widespread cross-infection of multiple RNA viruses across wild and managed bees. 2015, 84:615-624

75. Brown MJF, Jones CM: Parasites and genetic diversity in an invasive bumblebee. Journal of Animal Ecology 2014, 83:1428-1440.

76. Wilkinson EB, Feener DH: Variation in resource size distribution around colonies changes ant-parasitoid interactions. Insectes Sociaux 2010, 57:385-391.

77. Gordon DM: Behavioral flexibility and the foraging ecology of seed-eating ants. American Naturalist 1991, 138:379-411.

78. Ingram KK, Pilko A, Heer J, Gordon DM: Colony life history and lifetime reproductive success of red harvester ant colonies. Journal of Animal Ecology 2013, 82:540-550.

79. Richardson T, Gorochowski T: Beyond contact-based transmission networks: the role of spatial coincidence. Journal of the Royal Society Interface 2015, 12.

80. Denier D, Bulmer MS: Variation in subterranean termite susceptibility to fatal infections by local Metarhizium soil isolates. Insectes Sociaux 2015, 62:219-226.

81. Fogarty S, Cote J, Sih A: Social personality polymorphism and the spread of invasive species: a model. American Naturalist 2011, 177:273-287.

82. Sih A, Cote J, Evans M, Fogarty S, Pruitt J: Ecological implications of behavioural syndromes. Ecology Letters 2012, 15:278-289.

83. Réale D, Garant D, Humphries MM, Bergeron P, Careau V, Montiglio P-O:

Personality and the emergence of the pace-of-life syndrome concept at 
the population level Philosophical Transactions of the Royal Society B 2010, 365:4051-4063.

84. Harris RJ, Moller H, Winterbourn MJ: Competition for honeydew between two social wasps in South Island beech forests, New Zealand. Insectes Sociaux 1994, 41:379-394.

85. Monceau K, Moreau J, Poidatz J, Bonnard 0, Thiery D: Behavioral syndrome in a native and an invasive hymenoptera species. Insect Science 2015, 22:541-548.

*Vespa crabro (native) foundresses vary greatly within their native range. Vespa velutina (invasive) foundresses vary less within the sympatric range of V. crabro, but overall their foundresses tend me more active, bolder, and more exploratory than the native species. These traits may influence their ecological success as invaders.

86. Wang J, Wurm Y, Nipitwattanaphon M, Riba-Grognuz O, Huang Y-C, Shoemaker D, Keller L: A Y-like social chromosome causes alternative colony organization in fire ants. Nature 2013, 493:664-668.

87. Lawson LP, Vander Meer RK, Shoemaker D: Male reproductive fitness and queen polyandry are linked to variation in the supergene $G p-9$ in the fire ant Solenopsis invicta. Proceedings of the Royal Society of London B: Biological Sciences 2012.

88. Vandermeer RK, Obin MS, Morel L: Nestmate recognition in fire ants: monogyne and polygyne populations. Edited by Vandermeer RK, Jaffe K, Cedeno A. Westview Press; 1991:322-328. 